\title{
РЕЦЕНЗІЯ \\ на монографію Собко Ганни Миколаївни «Психічне насильство: кримінологічні та кримінально-правові засади протидії»
}

Кваша 0. 0.

Актуальність монографічного дослідження професора кафедри кримінального права та кримінології Одеського державного університету внутрішніх справ Собко Ганни Миколаївни на тему «Психічне насильство: кримінологічні та кримінально-правові засади протидії» зумовлена теоретичними й практичними проблемами визначення сутності і значення психічного насильства в Україні та становить цінність для наукової діяльності, а надані матеріали мають достатній теоретичний рівень і суттєву практичну значимість.

Наявність казуальних норм у Кримінальному кодексі України досить часто не дає змогу притягнути до кримінальної відповідальності осіб, які вчинили діяння, поєднані із застосуванням психічного насильства, згідно з принципом верховенства права (ст. 8 Конституції України). Не сприяють реалізації його охоронної функції та втіленню принципу справедливості також прогалини в українському кримінальному законодавстві. На цьому етапі розвитку українського суспільства будь-яка галузь пов'язана з впливом на людину (від політики до засобів масової інформації, від педагогіки та психології до права), через що $є$ зростаюча небезпека замаскованих та інтенсивних форм маніпулювання і психологічного насильства.

Термін «психологічне насильство» вживається в таких правових актах: Конвенції про права дитини від 20 листопада 1989 р., Законі України «Про попередження насильства в сім'ї від 15 листопада 2001 р. й у декількох нормативно-правових актах, прийнятих для розвинення цього закону, Законі України «Про дошкільну освіту» від 11 липня 2001 р., Порядку виявлення та ведення обліку дітей службами у справах неповнолітніх, затвердженому Наказом Міністерства у справах сім'ї, дітей та молоді від 14 квітня 2004 р., а також у декількох правових актах, які регулюють сферу освіти, питання молоді, неповнолітніх та охорони здоров'я.

На державному рівні розроблені такі нормативні акти щодо подолання проблем, пов'язаних із психічним насильством: Концепція Загальнодержавної програми адаптації законодавства України до законодавства Європейського Союзу (схвалена Законом України від 21 листопада 2002 р. № 228-15), Перелік пріоритетних тематичних напрямів наукових досліджень і науково-технічних розробок на період до 2020 року (затверджений Постановою Кабінету Міністрів України від 7 вересня 2011 р. № 942), Закон України «Про запобігання та протидію домашньому насильству» від 7 грудня 2017 р. № 2229-VIII. Вони вплинули на кримінальне законодавство щодо відповідальності за психологічне насильство. Крім того, автором проведено анкетування працівників підрозділів поліції, які безпосередньо працюють із суб'єктами, що вчиняють психічне насильство, та жертвами цього насильства.

Психічне насильство як універсальна категорія потребує окремого наукового дослідження та залишається не досить вивченим у юридичній науці. Вирішення цієї проблеми вимагає застосування системного підходу до розгляду психічного насильства в межах Загальної та Особливої частин кримінального права. Необхідним і важливим $\epsilon$ розроблення ефективних заходів протидії застосуванню психічного насильства до особи в сучасній Україні.

Сьогодні в Україні $є$ велика кількість робіт, присвячених розкриттю поняття насильства, проте серед фахівців у галузі кримінального права та кримінології немає уніфікованого підходу до розуміння сутності психічного насильства та заходів протидії різним його видам.

Віддаючи належне своїм попередникам, автор рецензованої монографії слушно зауважує, що дотепер дослідники, аналізуючи цю проблему, не досить зосереджували увагу на методологічному апараті, не застосовуючи міждисциплінарний підхід в аналізі правових проблем регулювання цих суспільних відносин. На нашу думку, автор обрав найбільш оптимальну структуру роботи. Вона складається 3 передмови, у якій окреслено основні проблеми, що виникають у разі дослідження насильства загалом і психічного насильства зокрема, п'яти розділів та післямови, у якій визначено основні підсумки дослідження. Така структура монографії дала змогу досліднику повною мірою розкрити зміст основних проблем, пов'язаних з еволюцією історико-правових поглядів щодо психічного насильства, їх філософською інтерпретацією та місцем у системі дотримання міжнародних правових стандартів. Варто вказати на ґрунтовний підхід Г.М. Собко до обрання теоретико-методологічних засад дослідження, викладених у першому розділі монографії. Це, безумовно, допомагає сприйняттю непростих проблем, що розкриваються автором рецензованої роботи, і в низці випадків дає додаткові аргументи на користь позицій, які відстоює дослідник.

Другий розділ присвячений кримінально-правовій характеристиці психічного насильства. Особливу увагу автор приділяє об'єкту та предмету складу злочину, а також мотиву й меті. Проблемою є відсутність законодавчого визначення злочинів, пов'язаних із психічним насильством, що на практиці може призводити до неналежного розслідування таких злочинів i, як наслідок, зростання недовіри до правоохоронних органів із боку

Кваша О. О., 2019 
представників тих груп, щодо яких, як правило, відбуваються такі злочини.

На сторінках третього $\breve{~ и ~ ч е т в е р т о г о ~ р о з д і л і в ~}$ Г.М. Собко розглядає не тільки класифікацію способів вчинення психічного насильства, а й кримінологічні категорії, що присвячені насильству на побутовому, сімейному та інформаційному рівні. При цьому більшість висновків, зроблених автором, заслуговують на повну підтримку. Зокрема, не можна не погодитися з їі твердженням про те, що під час оцінки загального стану прав людини необхідно запропонувати для визначення сутності психічного насильства окремий підхід, відповідно до якого психічне насильство може бути розглянуте як ситуація міжособистісних відносин, яка полягає у кримінальному насильницькому психічному впливі на фізичну особу - суб'єкта кримінальних правовідносин та у сприйнятті такого впливу цим суб'єктом, що стає головною причиною завдання кримінальної насильницької психічної шкоди цьому суб'єкту.

Новаторським виглядає зміст заключного розділу монографії, у якому Г.М. Собко спробувала встановити головні напрями вдосконалення правового механізму запобігання злочинам, що вчиняються 3 використанням психічного насильства. Варто визнати, що спроба загалом виявилася вдалою, і це особливо актуально в контексті тих процесів, які відбуваються в сучасному правовому житті України.
Аналіз рецензованої роботи дає змогу зробити закономірний висновок, що автору щонайменше вдалося на досить професійному рівні узагальнити матеріал стосовно імплікацій та нормативної пропорційності прав і свобод людини й громадянина. Більше того, запропоноване дослідження дає змогу подолати застарілі методологічні підходи, пропонує новий дискурс щодо таких понять, як «психічне насильство», «нефізичне насильство», «примус» тощо, а також сприяє встановленню співвідношення прав людини та законодавчих положень у міжнародному й національному праві. Отже, монографію Г.М. Собко відрізняє ґрунтовність і переконливість викладу, потужний науковий апарат, у ній містяться важливі наукові висновки, лише частину яких було відображено в рецензії. Це дослідження, безумовно, не лише $\epsilon$ корисним для фахівців із кримінального права та кримінології, а й допоможе органам державної влади розробити практичні рекомендації щодо сучасного реформування законодавства України про кримінальну відповідальність.

Кваша О. 0., доктор юридичних наук, професор, провідний науковий співробітник відділу проблем кримінального права, кримінології та судоустрою Інституту держави і права імені В. М. Корецького Начіональної академії наук України 